the pipo-drainage gystem, which is not only more economial, but more effectual. The whole drainage scheme of the metropolis, in short, must be discussed by the new Boand, de norr; and we hope, in the conflict of opinions which will necessarily result, to see a really good plan of drainage elaborated ; a matter of the utmost importance, as it lies at the foundation of the future health of the metropolis.

The instructions issued by the General Board of Health regarding the duties of the medical officers to be appointed under the new Act, indicate pretty clearly that a high standard of qualification is looked for in the future health officers; but no hint is given in that document either as to the best manner of selecting the candidates, or as to what the salary shall be. The report of the Paddington vestry gives the first note upon the subject, and the profession will, we think, feel inclined to approve of their recommendations. The vestry have done well in repudiating any immediate selection of the medical officer, on the ground that they can have no experience whatever of the duties that will be required of them. In order to obtain the best man, the report recommends that out of the following list, Dr. Baly, Dr. Tweedie, Dr. Alfred Taylor, Dr. Arnott, Dr. Lyon Playfair, and Mr. Paget, three be selected to sift out the five best qualified candidates for the post, from whom the restry will ultimately make their choice. This plan seems well calculated to put an end to the system of canvassing, which has been carried on to such an enormous extent for the new appointments, in some of which the personal interests of the electors are appealed to in a manner not calculated, we think, to strengthen their sense of public duty. For instance, in one of the testimonials of a candidate forwarded to us, occurs the following passage :-

"A landlord myself, as the proprietor of land, gardens, and houses in my native parish, in the county of I can, in some measure, estimate at their proper value not only the duties but the rights of property; and these, I hold, should be always carefully maintained, for, in iny judgment, property may be libelled as well as character."

Now, although the above passage may have been, and doubtless was, written in perfectly good faith, yet there can be nodoubt it would give the writer an unfair advantage over his competitors in the eyes of the small tradesmen who carry such weight at restry elections; this unfair advantage would tell for nothing, however, before such gentlemen as the Paddington Committee named as referees in the matter; hence our approval of their plan. The Committee estimate the value of the time of their future health officer at $£ 300$ per annum, with liberty to practise; this is, we think, a fair but not an over liberal salary. We hear that it is the intention to divide the duties in some large parishes, such as St. George's, Hanover Square: we trust that, if this is done, the salary of one good man will not be divided between two inefficient ones.

We rejoice to find that the price of prorisions has fallen in the metropolis since nii- last. Most of the diseases of the poor have their foundation in a deficiency of food, as the bands of half-starved creatures in the out-patient rooms of our hospitals prove. We may therefore look upon a more plentiful supply of food as the forerunner of a decreased mortality among the working classes.

The inquest on the bodies of Walter and Mary Palmer has been again adjourned at the request of Drs. Taylor and
Roes, who have not yet completed their experiments, in order to discover whether or not poison is to be found in their remains. It is scarcely necessary to state that the reports which have been going the round of the provincial papers, to the effect that a small portion of arsenic has been found in the body of the prisoner's wife, are totally without foundation, inasmuch as no report of the incomplete analyses has been made public. We very much regret to state that there can no longer be any doubt that the accused is a member of the College of Surgeons of England; his name is to be found on the register of 1816 , and he served the office of house-surgeon at St. Bartholomew's Hospital some time previously.

\section{HISTORY OF THE JOURNAL.}

\section{By W. A. GREENHILI, M.D.}

SIR,-The accompanying paper contains the substance of some observations made at the late Special General Meeting of the South Eastern Branch (Oct. 25th), which were received with some degree of interest and attention, and which may possibly contain some facts unknown to many of your readers.

In selecting the materials for writing the history of the Journal, I have confined myself (I believe, entirely) to official documents, and the letters and speeches of the officers of the Association; I have also, whenever it was practicable, used their words, rather than my own. By this means, I hope to have succeeded in my attempt to treat all parties and persons with perfect fairness and impartiality; and, indeed, I shall be sorry if any word or expression in this paper enables any of your readers to discover the writer's own opinion on the merits and management of the Journal. It is hardly to be expected that all parties will be pleased with what is here said; but it is hoped that, at least, no one will have any just ground to take offence. I have done little more than give a bare statement of facts, in order that each member may draw from them his own unbiassed conclusions; and also, because I am inclined to think that this sketch of the origin, rise, and progress of the Journal, if fairly written, may be of some interest and ralue in itself to all the members of the Association, quite independent of the writer, while my own opinion on so controverted a subject, which I hope to be allowed to send you in a separate form, will, of course, be considered by many members (perhaps by most) to be erroneous and worthless.

Lastly, as this paper may possibly contain errors, either of omission or commission (though none, $I$ hope, of importance), I shall be glad to have them pointed out; but, as they certainly have not arisen from wilfulness, or even from carelessness, perhaps it is not too much to ask they may be corrected with good temper and indulgence.

$$
\text { I am, ete., W. A. GreexhmL, M.D. }
$$

Hastings, December 5 th, 1355.

The Provincial Medicat and Strgical Association was founded in $183 \%$. In the original body of rules there is no mention of a Journal in connexion with the Association, but cnly of the "Transactions of the Association," which were to be published at Worcester. (See Trans., vol. i, p. 4.) The first volume of Transactions was published in 1833 , the nineteenth (and last) in 1853. They were edited by the secretaries (who were originally two in namber, and were to reside at Worcester), under the superintendence of the Council.

In 1810 the Provincial Medical and Surgical Journal was originated by Dr. Hennis Green, of London. It was not at first officially connected with the Association; but in the Introductory Address it was stated that two of the most important objects of the new Journal were, "the affording a special means of communication for the several medical and branch associations which have been formed in rarious parts of the kingdom, and 
the promotion, as far as possible, of the interests of these ad. mirable institutions, and more especially of those of the Provincial Association." Accordingly, Dr. Groen requested that one of the members of the Worcester Council might be connected with him as co-editor, and Dr. Streeten, of Worcester, was fixed upon. (Prov. Med. and Surg. Jour., 1819, p. 319.) The Journal was printed and published in London weekly, price sixpence, unstamped, and was not, externally, inferior to the other medical periodicals, with which it competed respectably, if not successfully.

In 1841, at the Anniversary Meeting at York, the Conncil reported " that they had for some time been engaged in endeavouring to mature a plan, by which every member of the 1 ssociation, whose subscription was not in arrear, would receive every week, without any additional subscription . a copy of the Provincial Journal." (Prov. Med. and Surg. Journ., vol. ii, p. 401.)

In 1842, at the Anniversary Meeting at Exeter, the Council reported that "the editors of the Provincial Journal, actuated by the most liberal views towards the Association, had enabled the Council to purchase at a reduced price the number of copies necessary for the members of the Association, who thas, for the small annual subscription of one guinea, had supplied to them an annual volume of Transactions and a weekly medical periolical." (Prov. Med. Jour., 1842, vol. i, p. 386.) And in the tenth volume of the Transactions (published in 1842), appears for the first time the law that "every member shall receive weekly \& copy of the Provincial Medical and Surgical Journal." (Law ix, p. 357.)

In 184:3, at the Anniversary Meeting at Leeds, the Council reported that " the Provincial Medical Journal had been steadily supplied throughout the year to members not in arrear, and that they had every reason to believe they should come to an arrangement with the proprietors to continue it at a small additional cost to the Association." (Prov. Med. Jour., vol. vi, p. 367.)

At the same meeting Dr. Streeten was appointed secretary of the Association, at a sulary of $£ 100$ (105?) a-year, in the place of Sir Charles Hastings and Mr. Sheppard, who had hitherto acted as conjoint honurary secretaries. (Ibid., p. 372.) It was not therefore at first anticipated that there would be any impropriety in allowing the same individual to act as editor of the Journal as well as secretary of the Association, and, in fact, Dr. Streeten held both offices till his death in May 1849.

In the beginning of 1844 it was determined that the Journal should be ufticially connected with the Association, edited by Dr. Streeten alone under the control of the Council, and printed and published at Worcester, price fourpence, unstamped. At the Anniversary Meeting at Northampton, the Council reported that after the meeting at Leeds, an " arrangement with the proprietors of the Provincial Medical Journal was entered into, and the Journal duly forwarded as before. At the expiration of a few weeks, however, an application for a still further increase in the sum allotted for this purpose was made... After several applications therefore for a further increase of the amount paid for the Journal, and the final proposal of terms which the Council did not feel themselves justified in accelin: to, the Council, after mature deliberation, came to the conclusion that the then existing arrangements between the Association and the proprietors of the Journal could no longer be carried out with advantage or satisfaction to either party... On the last proposals made by the acting proprietor being submitted to them early in Jannary last, the Council resolved, that, after the termination of the volume, a weekly periodical should be published, devoted solely and expressly to the interests of the Association... Accordingly, the Journal has since this period been issued directly under the control of the Council." (Prov. Med. and Surg. Jour., 1844, p. 301.)

The account of this transaction given by Mr. Renshaw, the publisher and one of the proprietors of the Journal, states that "the transfer of the Journal to Worcester was adopted by the Central Council in a resolution which bears date January 13th, 1844 , in consequence of an application by Mr. Renshaw, as one of the proprietors of the Journal, for such an increase on the price paid, namely, twopence halfpenny per number, stamped, as would make it remunerative, and enable him to give gentlemen of talent a proper recompense for their labours in the ditorial department, and to compete successfully with the exertions of other medical journals." He also states that the Journal "had been supplied to the Association considerably nnder cost price." (Prov. MIcd. Jour., vol. vii, p. 489.)

Whether the Jcurnal was intrinsically improved by this change may be doubted, but there can be no difference of opinion as to the great and immediate deterioration of its appearance as respects paper, printing, etc. One of the first consequences of this adoption of the Journal by the Association, was the claim for compensation made by Dr. Green, the late editor, who stated that " the establishment of the Journal had cost him much labour and expense, and then the Association had stepped in and appropriated the benefit of his exertions... He also put it to them whether the Association had any right to call the Journal their property until a general meeting had passed a vote to purchase it." (Prov. Med. and Surg. Jour., 1844, p. 311.) This claim was referred to arbitration, the award was in favour of $\mathrm{Dr}$. Green, and the amount of compensation adjudged was $£ 516: 11: 4$ (Ibid., 1845, p. 408), - a sum which was not raised without considerable difficulty, and was paid partly by a voluntary subscription among the members, but chiefly from the general funds of the Association. (Ibid., 1816, p. 397 ; 1847 , pp. 426,427 ).

Another immediate consequence of the official connexion of the Jourual with the Association, was the commencement of the vira voce discussions and controversial letters as to its merits and management, which have continued almost without intermission ever since that date, and the appointment of the first of the many Committees that have from time to time had to deliberate on the subject. In 1844 , at the Northampton Meeting, it was proposed by Dr. Inglis, of Halifax, "that for the extension of the projects of the Association with respect to their weekly Journal, and to enable them to continue the publication of their annual volume of Transactions, the subscription, instead of being ... one guinea, be henceforth one guinea and a half." (Ibid., 194t, p. 310.) The motion was only seconded as a matter of form ; and an amendment was carried "that a Committee be appointed to take into consideration whether it be expedient for the Association to continue the publication of a weekly medical periodical." The Committee consisted of Drs. Budd, Toogood, Cowan, Black, and Favell, and Messrs. Soden, Estlin, Smith, Wickham, and Newnham. (Ibid., p. 311.)

In 1845, at the Sheffield Meeting Dr. Toogood stated "that eight members of the Committee met at Bristol, but could not come to any final determination; and that he was, therefore, not able to lay any report before the Association." (Ibid. 1845, p. 505 .

At the same meeting a motion liy Sir Charles Hastings was carried, "that it is expedient to continue the publication of the Transactions and of the Journal for the next year, but it is necessary to lessen the expense of the same; on which account for the future the size of the Journal shall not exceed sixteen pages weekly, and the Central Council are also requested to endeavour to diminish the amount expended upon the Transactions." In his speech Sir Charles Hastings stated, that, "if the resolution were adopted, the result would be that the publicatinn of the Transactions and Journal need not exceed $\perp^{\prime} 1,000$ per annum." (Ibid., p. 506.)

In 1816, the Bath and Bristol Branch passed a series of resolutions on the sulject of the publications of the Association rearetting that they should ausorb almost the whole of the funds (amounting to about $£ 2,000$ per annum), and recommending "that the Journal be published in future but once 8 fortnight, or once a month, .... and that the volume of Transactions be altogether given up, or if continued, be .... published from time to time", \&c. (Ibid., 1846, p. 402). And about the same time the East York Branch passed a resolution, " that in the opinion of the Meeting it is expedient that the publication of the Provincial Medical and Surgical Journal be discon tinued", \&c. (Ibid.)

In the same year, at the Anniversary Meeting at Norwich, another Comrittee was appointed " to inquire whether any, and what alteration was required or desirable in the general publications of the Society." The Committee consisted of Drs. Budd, Cooper, Barker, Lyon, Hastings, Mackness, Radford, and Ranking, and Messrs. Peter Martin, Soden, Bree, Newnham, and Crosse (Ibid.); but the list of names appended to the report is somewhat different. (Ibid. 1847, p. 2.) The Com mittee "divided the object of their inquiry into two parts : 1. As to the propriety of making any change in the form and period of publication of the Journal and Transactions; and 2. As to the best means of giving the highest possible character to the literature of the Association." The Committee "having de-

* This fact appears at first sight inconsistent with the statement made by the Treasurer at the York meeting, "that, until the disastrous meeting at Oxford in 1852. we never had such a thing as a financial difficulty." (Arsoc. Ired. Jowrmal, 1855. p. 792.) There is, however, room for difference of opinion as to whether the raising this $\$ 516$ should be considered " a fanacial diffi"ulty", or not. 
voted considerable altention to the subject, and obtained the opinions of many imfluential members of the Association", precented towards the end of the year a carefully-written report on the former of these questions, which deserves perusal, but hioh cannot be fully analysed here. The Committee recommended, 1. That the Transactions should be published nccacionally, insteed of annually; 2. that the Jourmal should be published fortnightly, instead of weekly, by which change $2 \cdot 200$ - year wonld be saved in stamps alone; 3. that its size should be doubled, and 4. that a Sub-Editor, with a commensurate salary, should be appointed. (Illid.)

At a meeting of the Central (or Worcester) Council held Dec. 18, 1816, it was determined to adopt immediately two of the above rocommendations; and accordingly the Journal, consistin of thirty two pages (price 9d. stamped, was published fortnightly from the commencement of 1847 , and continued to appear in this form till the end of 1852 . The question of a Sub-Editor was left to the consideration of the next General Meeting at Ierby (Ibid., p. :3), when the Publications' Committee presented a detailed Report on the second part of their inquiry mentioned above, viz., "the best means of giving the highest possible character to the literature of : ie Association." The recommendations of the Committee were (briefly) as folows:- $l$. to endeavour to procure communications from Pro. rincial Hospitals and Medical Societies; 2 . also from private practitioners; 3. to appoint an additional Editor of the Journal to preside over a new department, to be called the Foreign Department 4 . to offer every facility in the Journal to Mr. Hunt and Mr. Crompton for carrving out their respective propositions for collecting materials for a Report on the Medicinal Action und Effects of Arsenic, and one on the Treatment of Burns and Scalds; and 5. To offer gold medals as prizes for valuable communications. (Ibid., p. 431.)

The Report was adopted, and the recommendations carried out as fur as possible. Dr. Ranking was appointed to conduct the Foreign Department; but I have been unable to discover by whom the appointment was made, or probably I may have overlooked the announcement in the Journal.

In the detailed statement of the accounts of the Association for the year 1840-7 (the earliest $I$ have been able to find,) the cost of the Transactions was L.36t, and that of the Journal (including stamps) 2638 ; no charge appears for editing the Journal. (Ibid., p. 427.)

In 1817.8, the cost of printing the Journal (including paper, stamps, etc.) was $£ 800$; plates and wood cits, etc. for the

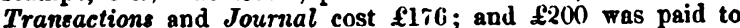
the Editors. (Ibid., 1848, p. 456.) By what authority the salary of the Editors was fixed at $\{200$ does not appear in the Journal (unless I have overlooked it); but few persons will consider this sum too large to be paid by an influential Society with a good income to the Editors of a Journal which (in the opinion of the Publications' Committee) " should hold a position not inferior to any other similar publication in the United Kingdom." (Ibid., 1847, p. 2.)

In May 18+y, Dr. Streeten died. At the next Anniversary Heeting at Worcester it was stated in the Report of the Council that " they were of opinion that the offices of Secretary and of Editor of the Journal combined were too laborious for any one individual, and they recommended that in future they shontd not be both held by the same person." They advised that Mr. Sheppard should be elected Secretary, and that a Committee should be appointed, who should be empowered to choose an Editor. (Ibid., 1849, p. 426.)

Accordingly Mr. Sheppard was appointed Secretary, and a Committee, consisting of the President (Sir Charles Hastings) and Vice-Presidents of the Association, was "empowered to fill up the oftice of Editor of the Journal, and to report their appointment to the Council within three months, such appointment being subject to confirmation or rejection ut the Anniversary Meeting in 1850." A motion, that the names of Dis. Forbes, Budd, Greenhill, Cowan, and Bell, be added to the Committee, was lost; as was also a motion "that the Committee should make an inquiry into the business of the Journal, more especially with reference to the cost of its production, and also as to whether it was desirable that it should be continued to be printed at Worcester." (Ibid., pp. 428, 429.)

In September 1849 the Committee “ unanimously appointed Dr. Ranking, of Norwich, and Mr. Walsh, of Worcester, conjoint Editors of the Journal of the Association." (Ibid., p. 532.) Shortly afterwards a marked improvement took place in the where continued as clean and neat-looking as any journal need be.

1n 1848.9 the sixteenth volume of the Transactions cost
E431); the plates and wood-cuts, etc. for Transactions and Journal, E91; printing the Journal, stamps, etc., \&700; and aliting the Journal, \&208. The reason for the increased cont of editing the Journal was not stated in the Report of the Comoil (Ibid., p. 426), nor by whose authority the salary of the Editors was increased.

At the Anniversary Neeting at Hull in 1850, the appointment of the conjoint Editors of the Journal was confirmed, but not without considerable discussion as to whether the Committe had not exceeded their powers in appointing two Editors instead of one. (Ibid., 1850, p. 156 .)

At the same meeting a letter was read from the president and the sam the South Eastern Branch, in justification of a formal censure passed on the editors of the Journal at a meet ing of that Branch, for their "want of candour and fairness" in discussing the question of medical reform. The writers blame the editors for "having, during the last fonr months, been engaged in controversy, at one time with the Lancet, at another with the Medical Times;" but they "have pleasure in bearing testimony to the good arrangement and valuable contents of the Journal." (Ibid., p. 450.) Whether the charges brought arainst the editors were well or ill-foundel need not be again discussed, but the letter may serve, at any rate, as a useful illustration of the difficulty that the editor of the Journal must find in expressing his opinion (especially on controverted points) in such a manner as not to offend some of his two thousand masters.

At the same meeting another Committee (consisting of Sir Charles Hastings, Drs. Robertson, Conolly, and Lyon, and Mr. Soden) was appointed " to consider whether any and what further improvements can be effected in the publications of the $\Lambda$ ssociaimprovements can be effected in the publications of the Associathe Brighton Meeting, they recommend " that the Journal should be published once a fortnight, and a volume of Transactions annually, biennially, or triennially, according to the accumulation of important papers;" they say that " the conjoint editorship does not appear to have been fraught with any inconrenience;" they "think the Reviews in the Journal should be analytical rather than critical, and that acrimonions reviews, like acrimonious correspondence, should be excluded;" they " do not recommend the suppression of the editorial or leading articles," "provided the topics are selected so as to steer clear of con' "provi" they add a few more remarks, and consider tha "the Journel has been so well edited for months past, that to a great extent it fulfils what the Committee bave been endea vouring to set forth." (Ibid., 1851, p. 458.)

In $1849-50$ the cost of "printing and Trausactions" was $£ 132$; and of the Journal $£: 32$, including $\mathfrak{E}^{2} 39$ for " Journal arrears ;" and salary of the editors was $f^{23 \%} \%$. (Ibid., 1851, p. 504.)

In 1850-1 the cost of "Transactions and general [printing] account" was £181; of plates, stamps, and binding of Transactions, $£ 112$; and of the Journal, $£ 843$, including $£ 181$ for "arrears for 1850;" the salary of the editors was £250. (Ibid., 1851, p. 304.)*

In 1851-2 the cost of the Journal was fi32; the salary of the editors, $£ 250$; the cost of "printing and Transactions" was f225; other expenses connected with the publications of the Association amounted to $£ 132$. (Ibid., 185\%, p. 403.)

[To be continued.]

\section{Association entelligence.}

\section{BIRMINGHAM AND MIDLAND COUNTIES BRANCH: GENERAL MEETING.}

A General Meeting of the Birmingham and Midland Counties Branch was held on December 13th, 1855, Lasgstos PARER, Esq., President, in the chair.

There were also present: G. J. Brown, Fsq. (Birmingham); E. Chesshire, Esq. ( Birmingham); Pye Chavasse, Esq. (Birmingham); J. Davies, Esq. (Dudley Port); G. Elkington, Esq. (Birmingham); J.J. Hadley, Esq. (Birmingham): Alfred Hill, M.D. (Birmingham); W. Hinds, N.D. (Birmingham); G.Jones,

- The item of Journal arrears, which occurs in both these financial state- The item of Jolirnal arrears, which ocistent with the statement made by ments, appears at fir York meeting "that, untll the Oxford meoting, we were the Treasurer at the York metion than having all our bills paid, and a small never once in any other position halance in the hands of the Troast inconsisteney admits of explanation-it certain!y requires it. 